\title{
Evaluation of the virtual learning object "Diagnostic reasoning in nursing applied to preterm newborns"
}

\author{
Fernanda dos Santos Nogueira de Góes ${ }^{1}$ \\ Luciana Mara Monti Fonseca² \\ Maria Cândida de Carvalho Furtado² \\ Adriana Moraes Leite ${ }^{2}$ \\ Carmen Gracinda Silvan Scochi ${ }^{3}$
}

The potential use of computer technology in teaching and continuous education for nursing motivated the development of this study to evaluate the virtual learning object, "Diagnostic Reasoning in Nursing Applied to Preterm Newborns" at an intermediate neonatal care unit. This descriptive study evaluates the appearance and content of the virtual object concerning aspects related to presentation, organization, usability and overall impression. Experts from the fields of computer technology (12) and nursing (31) participated in the evaluation process. Each sub-item of the instrument was assessed on a Likert scale and blank space was provided for comments/ suggestions. All items were positively evaluated by over $80 \%$ of the experts, except for the 'informational density' criterion in the evaluation performed by computer technology experts. The developed product is considered adequate to be used for teaching for nursing students and in continuous education of diagnostic reasoning in the development of Nursing Diagnoses for preterm newborns, in the problem-posing pedagogical framework.

Descriptors: Neonatal Nursing; Infant, Premature; Nursing Diagnosis; Computer-Assisted Instruction.

\footnotetext{
${ }^{1}$ RN, Doctoral Student, Escola de Enfermagem de Ribeirão Preto, Universidade de São Paulo, WHO Collaborating Centre for Nursing Research Development, SP, Brazil. E-mail: fersnogueira@hotmail.com.

${ }^{2}$ RN, Ph.D. in Nursing, Professor, Escola de Enfermagem de Ribeirão Preto, Universidade de São Paulo, WHO Collaborating Centre for Nursing Research Development, SP, Brazil. E-mail: Luciana - lumonti@eerp.usp.br, Maria Cândida - mcandida@eerp.usp.br, Adriana - drileite@eerp.usp.br.

${ }^{3}$ RN, Ph.D. in Nursing, Full Professor, Escola de Enfermagem de Ribeirão Preto, Universidade de São Paulo, WHO Collaborating Centre for Nursing Research Development, SP, Brazil. E-mail: cscochi@eerp.usp.br.
}

Corresponding Author:

Carmen Gracinda Silvan Scochi

Universidade de São Paulo. Escola de Enfermagem de Ribeirão Preto

Departamento Materno-Infantil e Saúde Pública

Av. dos Bandeirantes, 3900

Bairro: Monte Alegre

CEP: 14040-902, Ribeirão Preto, SP, Brasi

E-mail: cscochi@eerp.usp.br 


\title{
Avaliação do objeto virtual de aprendizagem "Raciocínio diagnóstico em enfermagem aplicado ao prematuro"
}

Vislumbrando o potencial de uso da informática, na formação e educação permanente em enfermagem, realizou-se o presente estudo com o objetivo de avaliar objeto virtual de aprendizagem raciocínio diagnóstico em enfermagem aplicado ao prematuro, em unidade de cuidado intermediário neonatal. Trata-se de estudo descritivo sobre a avaliação da aparência e conteúdo do objeto virtual, nos aspectos relacionados à apresentação, organização, usabilidade e impressão geral. Participaram peritos das áreas de informática (12) e enfermagem (31). Cada subitem dos instrumentos continha avaliação em escala Likert e espaço para inclusão de comentários/sugestões. Todos os itens foram avaliados positivamente por mais de $80 \%$ dos avaliadores, exceto o critério densidade informacional na avaliação dos profissionais de informática. Considera-se que o produto desenvolvido está adequado para ser disponibilizado para uso no ensino de estudantes e educação permanente de enfermeiros, sobre raciocínio diagnóstico na elaboração de diagnósticos de enfermagem, aplicados ao prematuro, inserido no referencial pedagógico da problematização.

Descritores: Enfermagem Neonatal; Prematuro; Diagnóstico de Enfermagem; Instrução por Computador.

\section{Evaluación del objeto virtual de aprendizaje "Raciocinio diagnóstico en enfermería aplicado al prematuro"}

\begin{abstract}
Vislumbrando el potencial de uso de la informática en la formación y educación permanente en enfermería, se realizó el presente estudio con el objetivo de evaluar el objeto virtual de aprendizaje "Raciocinio Diagnóstico en Enfermería Aplicado al Prematuro" en una unidad de cuidado intermedio neonatal. Se trata de un estudio descriptivo sobre la evaluación de la apariencia y contenido del objeto virtual en los aspectos relacionados a la presentación, organización, usabilidad e impresión general. Participaron peritos de las áreas de informática (12) y enfermería (31). Cada sub-ítem de los instrumentos contenía evaluación en escala tipo Likert y espacio para inclusión de comentarios/sugerencias. Todos los ítems fueron evaluados positivamente por más de $80 \%$ de los evaluadores, excepto el criterio densidad de información en la evaluación de los profesionales de informática. Se considera que el producto desarrollado está adecuado para ser colocado a disposición para uso en la enseñanza de estudiantes y en la educación permanente de enfermeros sobre raciocinio diagnóstico en la elaboración de Diagnósticos de Enfermería aplicados al prematuro, dentro del marco pedagógico de la problematización.

Descriptores: Enfermería Neonatal; Prematuro; Diagnóstico de Enfermería; Instrucción por Computador.
\end{abstract}

\section{Introduction}

Understanding Nursing Diagnoses as a phase of the nursing process that involves clinical judgment that corresponds to the intellectual endeavor in which collected information is analyzed, judged and gathered to define a diagnosis, is often a difficult task for nursing professionals $^{(1)}$
There are many definitions in the health field for the process of making a diagnosis, such as judgment, clinical reasoning and diagnostic reasoning(2), which can be defined as the process of clinically reasoning to recognize relevant diagnoses, that is, a type of clinical reasoning aimed to establish the diagnosis that best 
expresses the health state of individuals, families or community ${ }^{(3)}$.

A didactic resource used to enable nursing students and nurses to better understand the nursing process and diagnosis reasoning is to treat these from a linear point of view, which however, does not allow students to visualize how the stages are interconnected or interdependent ${ }^{(2)}$.

From this perspective, the search for scientific improvement to advance teaching and qualification is essential because the job market requires professionals to have knowledge to work in the systematization of nursing care $^{(4)}$.

There is a lack of studies addressing Nursing Diagnosis and diagnostic reasoning specifically in the field of neonatal nursing care provided to preterm newborns. Only six studies published in the last five years focused on preterm newborns and their families.

The teaching of Nursing Diagnoses and diagnostic reasoning in neonatal nursing can benefit from technology, which can help qualify competent nurses in the nursing process contributing to improved quality of care delivered to preterm newborns and their families.

Because it permits the construction of repositories of classes to be accessed by various users and provide synchronous and asynchronous interaction tools, the use of Virtual Learning Environments (VLE) can be a teaching strategy used in the education and qualification of nurses concerning nursing diagnoses in care provided to preterm newborns ${ }^{(5)}$.

Many authors have reported the use of VLE in teaching nursing. However, only four studies used computer-based interactive resources to teach neonatal nursing and none used VLE, denoting the scarcity of research in the field.

Hence, this study evaluated the content and appearance of a virtual learning object inserted into a VLE addressing diagnostic reasoning in nursing related to preterm infants and their families in a neonatal intermediate care unit.

\section{Methods}

This descriptive study reports the evaluation of a virtual interactive learning object. The project was approved by the Research Ethics Committee (Process 5229/2008).

The virtual object was constructed using the multimedia-authoring tool Macromedia Authorware ${ }^{\circledR}$, inserted into a VLE, the Moodle.
The Macromedia Authorware ${ }^{\circledR}$ is acknowledged for its precision and efficiency ${ }^{(6)}$, able to gather text and multimedia resources in a single application, thus favoring interactivity.

Up to January 2010, Moodle registered more than 40 million users in more than 4 million programs, demonstrating that VLE is recognized as a pedagogical resource that helps students to improve cognition, construct knowledge, and promote positive attitudes through discussion and cooperation ${ }^{(7)}$.

The virtual object has a modular structure with theoretical content concerning nursing diagnoses: one module to teach diagnoses based on Risner's work and the NANDA taxonomy and another module containing simulations of procedures, in which seven clinical cases of preterm infants are distributed, totaling 72 nursing diagnoses.

Studies evaluating virtual objects or educational software have not used probabilistic samples because such evaluations require that the population have defined characteristics.

In relation to the number of evaluators, only one study used a sample greater than six evaluators from computer science ${ }^{(5)}$ and another used a sample greater than 15 nursing scorers ${ }^{(8)}$.

We invited 15 experts with bachelor degrees in computer science or related fields to identify operational errors in the system; 12 agreed to participate in the study and signed free and informed consent forms.

After an initial evaluation and technical corrections in the virtual object, we proceeded to the evaluation by nursing experts. A total of 43 Brazilian university hospitals and 43 undergraduate nursing programs were contacted through mail and email. Of these, 29 nurses and 22 professors expressed interest in participating in the evaluation of the virtual object in Moodle. However, only those who met the study criteria were included in the study: 17 nurses and 14 professors. These criteria, contained in an adapted instrument, characterize expert nurses ${ }^{(9)}$. The minimum score for such a characterization is 4 . All the selected raters scored between six and 11 and signed free and informed consent forms.

Evaluation instruments including both the fields of technology and pedagogy were searched for critical analysis of the application and an instrument(10) was then adapted to be used by both computer and nursing professionals. This instrument has been already used by a study conducted in Brazil(11). An instrument was adapted in the form of a checklist to permit evaluating 
the ergonomics of interface criteria, which were included to encompass those who study technology. Such an instrument was developed by professors from the Federal University of Santa Catarina and made available on the Internet ${ }^{(12)}$. The instruments presented statements concerning aspects related to the expert's field of evaluation, a Likert-type summative method, and a blank space for suggestions.

The instruments for computer science and nursing were evaluated in a pilot-test by three computer professionals and two nurses to identify potential difficulties of understanding the terms used. These evaluations helped clarify some of the instrument's expressions.

Data were collected between April and June 2010. The virtual learning object and respective instruments of evaluation were made available in Moodle and later sent to the researchers through email.

Descriptive statistics were used in analyzing data related to the evaluation process of the VLE. The items that reached $70 \%$ agreement among scorers, through concepts such as "agree" or "strongly agree", according to criterion adopted in other studies, were considered validated $^{(13-14)}$.

\section{Results}

\section{Evaluation - Computer Science}

The evaluation of the interactive virtual learning object "Diagnostic reasoning in nursing applied to preterm infants," performed jointly with computer science professionals, was composed of an instrument addressing a general impression concerning the presentation and organization of content (Table 1) and another addressing usability.

Concerning the general impression of the virtual object, table 1 shows there were no negative evaluations.

Table 1 - Evaluation concerning general impression of the virtual object of learning - Computer field. 2010

\begin{tabular}{|c|c|c|c|c|c|}
\hline \multirow{2}{*}{ General Impression } & \multicolumn{5}{|c|}{ Criteria } \\
\hline & Strongly disagree & Disagree & Agree & Strongly agree & Do not know \\
\hline $\begin{array}{l}\text { 1. The interface of the system/virtual learning object favors } \\
\text { learning the theme. }\end{array}$ & & & $6(50.0 \%)$ & $5(41.7 \%)$ & $1(8.3 \%)$ \\
\hline $\begin{array}{l}\text { 2. Presentation of content of the system/virtual learning object } \\
\text { favors learning the theme. }\end{array}$ & & & $5(41.7 \%)$ & $5(41.7 \%)$ & $2(16.6 \%)$ \\
\hline 3. Computer animations help learning the theme. & & & $7(58.3 \%))$ & $5(41.7 \%)$ & \\
\hline $\begin{array}{l}\text { 4. The system/virtual learning object is indicated to be used as } \\
\text { an educational tool. }\end{array}$ & & & $5(41.7 \%)$ & $6(50.0 \%)$ & $1(8.3 \%)$ \\
\hline $\begin{array}{l}\text { 5. The limitations of the virtual learning object do not exceed its } \\
\text { utility in the teaching of nursing. }\end{array}$ & & & $5(41.7 \%)$ & $5(41.7 \%)$ & $2(16.6 \%)$ \\
\hline $\begin{array}{l}\text { 6. I recommend the system/virtual learning object for the teaching } \\
\text { of neonatal nursing. }\end{array}$ & & & $5(41.7 \%)$ & $5(41.7 \%)$ & $2(16.6 \%)$ \\
\hline
\end{tabular}

The following suggestions were added: There are problems with the 'Exit' button on some screens of the Nursing Diagnosis module and gallery and problems going back to a previous page; Standardize fonts in the Nursing Diagnosis module... and ...some changes related to navigability are needed. All these suggestions were included in the virtual object before nurses evaluated it.

The statements concerning usability were grouped into criteria, which obtained the following agreement (agree and strongly agree): Grouping by format: 100\%; Quality of error messages: 100\%; Speed: 97.9\%; Grouping by localization: $97.2 \%$; Concision: $95.8 \%$; Immediate feedback: 94.4\%; Minimal actions: 91.6\%; Correction of errors: $91.7 \%$; Consistency: $91.7 \%$; Compatibility: 91.7\%; Readability: 89.6\%; User control: $83.4 \%$; Meaning of codes and names: $83.4 \%$; User's explicit actions 75.0\%; User's experience is considered: $75.0 \%$, and Informational density: $66.6 \%$.

Hence, all criteria of usability of the virtual learning object achieved the expected agreement (above 70\%), except 'Informational Density,' which achieved 66.6\% due to an excess of texts necessary to construct clinical cases. Four evaluators made observations concerning excess of text in clinical cases, but considered the remaining modules to be adequate.

\section{Evaluation - Nursing Field}

Given the extensive content in the virtual object, we divided the evaluation into four groups, whose compositions were: Groups 1 and 4: four professors and four nurses; Group 2: four professors and three nurses; Group 3: five professors and three nurses. The groups 1, 
2 and 3 evaluated a case in the teaching module and one simulation. Group 4 evaluated a case in the simulation module and the theoretical content module concerning nursing diagnosis, though, theoretical content was available to all the other groups for consultation.

After navigating through the virtual object, the experts answered the instruments for general impression (Table 2), content (Table 3) and usability evaluations.

Table 2 - Evaluation of the general impression of virtual learning object - nursing. 2010.

\begin{tabular}{|c|c|c|c|c|c|}
\hline \multirow{2}{*}{ General impression } & \multicolumn{5}{|c|}{ Criteria } \\
\hline & Strongly disagree & Disagree & Agree & Strongly agree & Do not know \\
\hline $\begin{array}{l}\text { 1. The virtual learning object is important for students learning } \\
\text { the theme. }\end{array}$ & & & $10(32.3 \%)$ & $21(67.7 \%)$ & \\
\hline $\begin{array}{l}\text { 2. The interface of the virtual learning object favors learning the } \\
\text { theme. }\end{array}$ & & & $13(41.9 \%)$ & $18(58.0 \%)$ & \\
\hline $\begin{array}{l}\text { 3. The content of the virtual learning object is important for } \\
\text { learning the theme. }\end{array}$ & & & $9(29.0 \%)$ & $22(71.0 \%)$ & \\
\hline 4. Computer animations help learning the theme. & & $2(6.4 \%)$ & $10(32.3 \%)$ & $18(58.0 \%)$ & $1(3.2 \%)$ \\
\hline $\begin{array}{l}\text { 5. The simulation of clinical cases is relevant to learning the } \\
\text { theme. }\end{array}$ & & & $10(32.3 \%)$ & $21(67.7 \%)$ & \\
\hline $\begin{array}{l}\text { 6. The system/virtual learning object is indicated to be used as } \\
\text { an educational tool. }\end{array}$ & & & $9(29.0 \%)$ & $22(71.0 \%)$ & \\
\hline $\begin{array}{l}\text { 7. The limitations of the virtual learning object are not greater } \\
\text { than its utility. }\end{array}$ & & & $15(48.3 \%)$ & $16(51.6 \%)$ & \\
\hline
\end{tabular}

All the items achieved $100 \%$ of agreement with exception of the item 4 (computer animation).

Table 3 - Evaluation of content of virtual learning environment - nursing. 2010

\begin{tabular}{|c|c|c|c|c|c|}
\hline \multirow{2}{*}{ Content } & \multicolumn{5}{|c|}{ Criteria } \\
\hline & Strongly disagree & Disagree & Agree & Strongly agree & Do not know \\
\hline $\begin{array}{l}\text { 1. The objectives of the system/virtual learning object are } \\
\text { clearly defined. }\end{array}$ & & & $10(32.3 \%)$ & $21(67.7 \%)$ & \\
\hline 2. Content is coherent with the target-public. & & $1(3.2 \%)$ & $11(35.5 \%)$ & $19(61.3 \%)$ & \\
\hline 3. The virtual learning object simulates reality well. & & & $10(32.3 \%)$ & $20(64.5 \%)$ & $1(3.2 \%)$ \\
\hline $\begin{array}{l}\text { 4. Interaction during the simulation of clinical cases is } \\
\text { satisfactory. }\end{array}$ & & $2(6.4 \%)$ & $14(45.2 \%)$ & $15(48.3 \%)$ & \\
\hline $\begin{array}{l}\text { 5. Presentation of figures is relevant to information included } \\
\text { in the text. }\end{array}$ & & $1(3.2 \%)$ & $7(22.6 \%)$ & $22(71.0 \%)$ & $1(3.2 \%)$ \\
\hline $\begin{array}{l}\text { 6. Presentation of videos is relevant to information included } \\
\text { in the text. }\end{array}$ & & $2(6.4 \%)$ & $12(38.7 \%)$ & $17(54.8 \%)$ & \\
\hline $\begin{array}{l}\text { 7. Presentation of sounds is relevant to the information } \\
\text { included in the text. }\end{array}$ & & $4(12.9 \%)$ & $13(41.9 \%)$ & $14(45.2 \%)$ & \\
\hline 8. Virtual learning object encourages learning. & & & $11(35.5 \%)$ & $20(64.5 \%)$ & \\
\hline $\begin{array}{l}\text { 9. Virtual learning object permits learning based on the } \\
\text { user's previous experience. }\end{array}$ & & & $16(51.6 \%)$ & $15(48.3 \%)$ & \\
\hline $\begin{array}{l}\text { 10. Virtual learning object facilitates retention of content in } \\
\text { the student's memory. }\end{array}$ & & $1(3.2 \%)$ & $11(35.5 \%)$ & $18(58.0 \%)$ & $1(3.2 \%)$ \\
\hline
\end{tabular}

All the items were positively evaluated with a percentage above $93 \%$ of agreement.

When the statements concerning the usability criteria were grouped, the following level of agreement (agree and strongly agree) was obtained: Speed: 95\%; Readability: 92.5\%; Grouping by location: $96.7 \%$; Consistency: 90.4\%; User control: 85.5\%; Immediate feedback: 93.3\%; Correction of errors: 93.6\%; and Error messages: $93.5 \%$.

\section{Discussion}

We realized over the course of this study that the use of computers in teaching nursing, specifically virtual learning objects, has been intensified in recent years, especially in teaching and research centers.

The option to use Moodle facilitated the participation of experts from other Brazilian regions and will also enable the dissemination of this virtual object of learning 
as resource aide in learning for teaching, research and care institutions.

Some evaluators of this virtual learning object reported difficulties accessing Moodle. We verified that the problems were related to difficulty handling the computer and the Internet or even not reading instructions on how to execute Moodle and the interactive object.

When users were qualified to use Moodle, they reported positive impressions concerning the environment and considered the platform easy to use. They also manifested their intention to transform the content of the their courses in virtual language ${ }^{(15)}$.

A limitation of this study is the proportion of individuals from the nursing field who were included in the study and did not achieve the minimum of ten evaluators per group. Nonetheless, small samples composed of experts in the nursing and/or computer fields have been used in studies evaluating virtual objects or educational software in nursing ${ }^{(5,11,13,16)}$.

A study ${ }^{(17)}$ analyzing interactive multimedia as a resource to be used in the teaching of semiology for nursing students verified that it is medium easy to use and a facilitator between theory and practice that improves understanding of theoretical classes.

The virtual object also presents limitations that may in part be related to the Authorware authoring software. The construction of content in this program requires the creation of a structure similar to a flow chart for events, tasks and decisions ${ }^{(18)}$ and, during the creation of this virtual object, we observed that the system was incapable of performing some necessary functions, resulting in the perception on the part of evaluators that there were deficiencies in the system, especially related to control (options to go back).

Another difficulty found is that it was not possible to execute the object directly in Moodle due to the size of the file, even after dividing it into smaller modules. For the evaluation to occur, it was necessary to install one executable file and send detailed instructions to the experts.

Other authors ${ }^{(19)}$ also reported limitations in relation to Authorware that could not be resolved due to the system's format, which reduced possibilities of interaction. Hence, we suggest new authoring software be used to create virtual learning objects that withstand different levels of complexity in actions.

In relation to this study's virtual object, its content received such recommendations because it was assessed by a group of experts in neonatology and in Nursing Diagnoses to bring the user into proximity of the context found in clinical practice and ensure appropriately structured theoretical content and that reliable clinical cases are available. Clinical cases are presented in this virtual object, allowing students to problematize real contexts $^{(20)}$.

Structuring the content of virtual learning objects into modules and in a non-linear manner enables users to navigate through content the way they like with flexibility, freedom respect for each one's own rhythm, and user's can actively participate in the construction of their own knowledge. All these are premises of a problem-posing education ${ }^{(20)}$.

In relation to the evaluation of the virtual object's usability, the great advantage in testing it lies in discovering problems that can represent difficulties in course development ${ }^{(16)}$.

We believe that the option to evaluate usability criteria based on the criteria of the ergonomics of interface enabled the analysis of technical aspects relevant to learning. Such aspects can facilitate or hinder navigation and consequently either encourage or compromise learning. However nursing studies conducting ergonomic evaluations similar to the evaluation conducted in this study were not found.

Only the criterion of 'informational density' was considered inadequate by computer professionals, though it was considered adequate by nurses.

Another study evaluated ergonomic criteria of a virtual environment of a clinical simulation of nursing in intensive therapy and the following were reported: the organization criterion scored 4.43 (maximum was 5 ); presentation scored 4.5 ; technical criterion related to appropriate functioning of links and download speed scored 4.79(11)

Evaluation of VLE in another study ${ }^{(21)}$ was similar to that of this study. Three computer experts evaluated time of response, quality of interface, tools and resources, educational aspects, quality of environments and didactic resources. Evaluations related to screen format, error messages, ease of use, links, logical sequence of menus, icons, and informational density were considered satisfactory or even excellent by two experts, while one expert considered the text, ease of use and links to be regular. The comments were centered on aspects related to clarification of navigation and instructions to execute modules(5).

In relation to the usability of the online course addressing care provided to critical patients, ease of navigation, quality and understanding of content were evaluated before it was distributed to students as adjuvant 
learning material. The nurses evaluated whether the course ensured active learning, feedback, interaction of students with the course, collaboration, and whether it presented multiple resources to encourage learning. On a scale from 1 to 5 , all the items scored from 2.63 (collaboration) to 4.2 (resources to encourage learning), while the general evaluation of satisfaction scored 4.17, which reflects great satisfaction with the course ${ }^{(16)}$.

Activities mediated by computer should ensure flexibility of time organization, site of study, rhythm of learning, access to coherent information and interaction(22). We believe that our virtual object plays such a role since its content is available on the Internet, facilitating its access from anywhere there is network connection. The student or nurse can navigate whenever is more convenient and establish his/her own rhythm of learning. Additionally, the fact the object is not constructed in a linear manner allows the user to interact the way $\mathrm{s} /$ he deems appropriate with freedom of choice.

From this perspective, interactivity motivates technology users and multimedia has a prominent role in this scenario(23).

Appropriate navigability is what allows users to "move" freely through the program, making the best use of information. The application of different media is frequent in educational software and increases the understanding of content ${ }^{(23)}$.

\section{Conclusion}

We constructed this virtual interactive learning object because we believe that the Nursing Process within care, which in this study focused on the stage of development of Nursing Diagnosis reasoning, coupled with computer technology, has a prominent role in the qualification of nurses.

Only two out of the 45 items evaluated by the computer experts, which refer to informational density, failed to achieve the established $70 \%$ of agreement (agree and strongly agree). All the 46 items evaluated by nursing professionals achieved the validation criteria.

Hence, we assert that the developed product is appropriate for use in the teaching of neonatal nursing and the qualification of nurses regarding Nursing Diagnosis in care provided to preterm infants and their families, included in the problem-posing pedagogical framework in light of basic human needs and the NANDA-I taxonomy, which can be a motivation for future studies.
The need to perform the last stages of implementation provided in the adopted software is apparent: it should be evaluated by the final users.

Therefore, it is necessary to develop further studies focusing on the impact of the virtual learning object on the teaching of the nursing process and the retention of knowledge by undergraduate students and nurses as they use it.

We conclude that the results obtained in this study can contribute to the adoption of educational practices based on the use of new computer technologies toward improving the quality of nursing education and the process of qualifying nurses.

\section{References}

1. Farias JN. Diagnósticos de enfermagem: uma abordagem conceitual e prática. João Pessoa: Santa Marta; 1990. 160 p.

2. Cruz DAL. Diagnósticos de enfermagem. In: Garcia TR, Egry EY, organizadores. Integralidade da atenção no SUS e sistematização da assistência de enfermagem. Porto Alegre: Artmed; 2010. 336 p.

3. Oliva APV. Banco de itens para avaliação de raciocínio diagnóstico [tese de doutorado]. São Paulo (SP): Escola de Enfermagem da Universidade de São Paulo; 2008. 84 p.

4. Cerullo JASB, Cruz DALM. Raciocínio clínico e pensamento crítico. Rev. Latino-Am. Enfermagem. 2010;18(1). [acesso 28 mar 2010]. Disponível em: http://www.scielo.br/pdf/rlae/v18n1/pt_19.pdf doi: 10.1590/S0104-11692010000100019.

5. Caetano KC. Desenvolvimento e avaliação de um ambiente virtual de aprendizagem em administração de enfermagem [dissertação de mestrado]. São Paulo (SP): Escola de Enfermagem da Universidade de São Paulo; 2006. 155 p.

6. Kasim VM, Silva OMR. Software de autoria apoiando aprendizagem. 2008 [acesso 28 mar 2010]. Disponível em: <http://www.pucpr.br/eventos/educere/ educere2008/anais/pdf/640_552.pdf $>$.

7. Martín-blas T, Serrano-Fernández A. The role of new technologies in the learning process. Moodle as a teaching toll in Physics. Computers Educ. 2009;52:3544.

8. Gibbins S, Maddalena P, Yamada J, Stevens P. Testing the satisfaction and feasibility of a computer-based teaching module in the neonatal intensive care unit. Advances in Neonatal Care. 2007;7(1):43-9. 
9. Fehring RJ. Methods to validate nursing diagnoses. Heart Lung. 1987;16(6):625-9.

10. Reeves TC, Harmon S. Educational WWW sites evaluation instrument. 1998. [acesso 14 mar 2010]. Disponível em: http://it.coe.uga.edu/ treeves/ edit8350/wwweval.html.

11. Barbosa SFF, Marin HF. Web-based simulation: a tool for teaching critical care nursing. Rev. Latino-Am. Enfermagem. 2009;17(1):7-13.

12. Ergolist. Ferramentas para usabilidade: checklists de usabilidade segundo os critérios ergonômicos de Bastien e Scapin. 2008. [acesso 15 nov. 2009]. Disponível em: <http://www.labiutil.inf.ufsc.br/ergolist/>.

13. Fernandes MGO, Barbosa VL, Naganuma M. Exame físico de enfermagem do recém-nascido a termo: software auto-instrucional. Rev. Latino-Am. Enfermagem. 2006; 14(2):243-50.

14. Fonseca LMM, Leite AM, Mello DF, Dalri MCB, Scochi CGS. Semiotécnica e semiologia do recém-nascido prétermo: avaliação de um software educacional. Acta Paul Enferm. 2008;21(4):543-8.

15. Masterman E, Jameson J, Walker S. Capturing teachers' experience of learning design through case studies. Distance Educ. 2009;30(2):223-38.

16. Jeffries PR. Development and testing of a hiperlearning model for design of an online critical care course. J Nurs Educ. 2005;44(8):366-72.

17. Santiago LC. A multimídia interativa como recurso didático-pedagógico para o ensino teórico-prático da semiologia em enfermagem [tese de doutorado]. Ribeirão Preto (SP): Escola de Enfermagem de Ribeirão Preto da Universidade de São Paulo; 2003. 118 p. 18. Adobe. Authorware suport tutorials. 2009. [acesso 12 abr. 2010]. Disponível em: <http://www.adobe.com/ support/authorware/tutorial_index.html>.

19. Ross GC, Tuovinen JE. Deep versus surface learning with multimedia in nursing education: development and evaluation of WoundCare. Comp Nurs. $2001 ; 19(5): 213-23$.

20. Freire P. Pedagogia do oprimido. 38.ed. Rio de Janeiro: Paz e Terra; 2004.

21. Rodrigues RCV. Ambiente virtual de aprendizagem em reanimação cardiorrespiratória em neonatologia [dissertação de mestrado]. São Paulo (SP): Escola de Enfermagem da Universidade de São Paulo; 2008. 185 p.

22. Dias DC, Cassiani SHB. Educação sem distâncias: utilização do WebCT como ferramenta de apoio para - ensino da terapia intravenosa na graduação em enfermagem. Rev Bras Enferm. 2003;56(4):443-6.
23. Lopes MVO, Silva VM, Araújo TL. Desenvolvimento lógico-matemático do software. Rev. Latino-Am. Enfermagem. 2004;12(1):92-100. 